\title{
Characteristics of Dried Noodles from Modified Sorghum Flour (MOSOF) (Sorghum bicolor)
}

\author{
Riski Ayu Anggreini ${ }^{1}$, Ulya Sarofa, Rosida \\ Departement of Food Technology \\ Universitas Pembangunan Nasional "Veteran", Jawa Timur \\ Surabaya, Indonesia \\ ${ }^{1}$ riskiayua.tp@upnjatim.ac.id
}

\begin{abstract}
Consumption of noodles in Indonesia is increasing and this has an impact on increasing imports of wheat flour. Sorghum is considered to have the potential to be used as a substitute for wheat flour, because it has a fairly good nutrient content. However, it has anti-nutritional properties which can reduce digestibility. To increase digestibility, sorghum flour is modified by fermentation using Lactobacillus plantarum (Modified Sorghum Flour / MOSOF). The use of MOSOF as a substitute for wheat flour cannot be $100 \%$, this is because there is no gluten content. Research using MOSOF substitution in dried noodle products is still rarely done, so this study determined the best formula of MOSOF as a substitute for wheat flour in making dried noodles. The results showed that fermentation can increase protein, starch and moisture component of sorgum flour. Besides, the proportion of 50:50 (wheat flour: MOSOF) and egg 25\% was chosen as the best treatment, because it can improve the physical and chemical quality of dried noodle products, including rehydration $(\%)$, elasticity $(\%)$, ash $(\% \mathrm{wb})$ and moisture $(\% \mathrm{wb})$ than 70:30 (wheat flour: MOSOF) $(\mathbf{p}<0.05)$.
\end{abstract} noodles

Keywords - sorghum flour modification, fermentation, dried

\section{INTRODUCTION}

Noodles are one of the foods that are popular in Asia, especially in Southeast Asia. Indonesia is one of country that can be categorized as consumptive of noodles. According to [1], Indonesia is the second largest consuming country in the world after China. The high consumption of noodles has an impact on increasing the use of wheat flour. The increase in demand for wheat flour can affect the increase in imports of wheat flour, and this is expected to increase. The high demand for wheat flour can be used as an opportunity to increase local food potential, namely by producing flour from local ingredients, such as sorghum. Sorghum is considered to have the potential for substitution of wheat flour based on the high nutritional content.

Sorghum is a group of cereals. Sorghum seeds contain carbohydrates by $84.16 \%$, fat $0.35 \%$ and proteins $3.58 \%$ [2]. Sorghum contains anti-nutrient substances, namely tannin and phytate which can have an impact on digestibility. One effort to increase the digestibility of sorghum is the modification of sorghum by fermentation (MOSOF). In addition to increasing digestibility, fermentation can also increase the content of sorghum nutrients such as proteins and carbohydrates, and can increase the ability of moisture binding. Increasing the ability of this moisture can be utilized in the development of the volume of dough. Sorghum flour is fermented using Lactobacillus plantarum which is considered safe for human consumption / GRAS (Generally Recognized As Safe).

Sorghum flour can be used as a substitute in making noodles, however, substitution cannot be $100 \%$. This is caused by lower proteins content of sorghum (3.58\%) [2], than wheat flour $(12.80 \%)$ [3]. In addition, sorghum also does not contain gluten which has an important role in the formation of noodle texture. In making noodle dough substituted with flour that does not contain gluten, other ingredients are needed to improve the quality of the noodles, so that the final dough is formed which is tough and does not break easily, one of which is egg. Egg can be used to improve the quality of the dough, which is as an emulsifier and prevents the turbidity of the noodles during cooking.

Research using MOSOF substitution in dried noodle products is still rarely done. For this reason, this study was designed to determine the best formula of modified sorghum flour as a substitute for wheat flour in making dried noodles.

\section{MATERIALS AND METHODS}

\section{A. Material}

Sorghum seeds was obtained from farmers in Madura and the bacterium Lactobacillus plantarum FNCC 0027 was obtained from the Center for Food and Nutrition Studies (PSPG) Gadjah Mada University Yogyakarta.

\section{B. Material preparation and chemical analysis} a. Sorghum Flour Starters

Preparation of sorghum flour starter is done by inoculating the rejuvenated Lactobacillus plantarum FNCC 0027, on sterile $5 \mathrm{ml}$ MRS broth media, then incubated at $37^{\circ} \mathrm{C}$ for 24 hours. Furthermore, The starter was poured aseptically into $100 \mathrm{ml}$ erlenmeyer which contained $5 \mathrm{~g}$ of sorghum flour and $15 \mathrm{ml}$ of distilled moisture. After that, the starter was incubated for 24 hours at $37^{\circ} \mathrm{C}$ [2].

b. Making Modified Sorghum Flour (MOSOF) and chemical analysis 
First, sorghum seeds were washed with destilled moisture, then it were soaked with $0.2 \%$ Na2HPO4 for 2 hours at $30^{\circ} \mathrm{C}$. After that, washing was done again using distilled moisture and dried for 3 hours at $65^{\circ} \mathrm{C}$, then it were crushed and sieved using dish mill (60 mesh). Then, the Sorghum flour is fermented by soaking using distilled moisture (1:3 b / v) and $10 \%$ in Lactobacillus plantarum inoculation, for 3 days. The next step is washing with distilled moisture, filtering and drying with $65^{\circ} \mathrm{C}$ for 2 hours. Furthermore, flour is refined and sieved with 80 mesh size [2].

The proximate properties (moisture, ash, proteins) and starch were determined as in [4] method, then crude fiber was determined as in [5].

\section{Making and Analyzing Dried Noodles a. Making Dried Noodles}

Dried noodles formula and its making process can be seen in Table 1 and figure 3.1., respectively.

b. Chemical and Physical analysis
The proximate composition (moisture, ash, proteins) and starch were measured following [4], then crude fiber was determined as [5]. Furthermore, Cooking loss, elasticity and rehidration were determined as [2].

\subsection{Experimental design}

This study uses a Completely Randomized Design with a factorial with 2 factors. The data obtained were analyzed using ANOVA and DMRT test with a 95\% confidence level using SPSS 19.

Variable change consists of 2 factors:

Factor I: Proportion of wheat flour with MOSOF

$$
\begin{aligned}
& \text { - } \mathrm{A} 1=50: 50 \\
& \text { - } \mathrm{A} 2=60: 40 \\
& \text { - } \mathrm{A} 3=70: 30
\end{aligned}
$$

Factor II: Addition of egg (\%)

- $\mathrm{B} 1=15$

- $\mathrm{B} 2=20$

- $\mathrm{B} 3=25$

TABLE I. DRIED NOODLE FORMULA ( $\mathrm{g})$

\begin{tabular}{|c|c|c|c|c|c|c|c|c|c|c|}
\hline Formula & I & II & III & IV & V & VI & VII & VIII & IX & X \\
\hline Wheat flour & 100 & 50 & 50 & 50 & 60 & 60 & 60 & 70 & 70 & 70 \\
\hline MOSOF & - & 50 & 50 & 50 & 40 & 40 & 40 & 30 & 30 & 30 \\
\hline GMS & 1 & 1 & 1 & 1 & 1 & 1 & 1 & 1 & 1 & 1 \\
\hline Egg & 15 & 15 & 20 & 25 & 15 & 20 & 25 & 15 & 20 & 25 \\
\hline Salt & 2 & 2 & 2 & 2 & 2 & 2 & 2 & 2 & 2 & 2 \\
\hline Palm oil & 10 & 10 & 10 & 10 & 10 & 10 & 10 & 10 & 10 & 10 \\
\hline Baking Powder & 0,5 & 0,5 & 0,5 & 0,5 & 0,5 & 0,5 & 0,5 & 0,5 & 0,5 & 0,5 \\
\hline Moisture & 50 & 50 & 50 & 50 & 50 & 50 & 50 & 50 & 50 & 50 \\
\hline Total & 178.5 & 178.5 & 183.5 & 188.5 & 178.5 & 183.5 & 188.5 & 178.5 & 183.5 & 188.5 \\
\hline
\end{tabular}

Source: Ariyanti (2016) [2]

TABLE II. CHEMICAL PROPERTIES OF MOSOF (\%WB)

\begin{tabular}{|c|c|c|}
\hline Components & Sorghum Flour & MOSOF \\
\hline Moisture & $10,43^{\mathrm{a}}$ & 11.21 \\
\hline Ash & $1,48^{\mathrm{a}}$ & 1.14 \\
\hline Proteins & $3,58^{\mathrm{a}}$ & 5.03 \\
\hline Crude Fibre & $2,63^{\mathrm{a}}$ & 0.58 \\
\hline Starch & $\left(44.85^{\mathrm{b}}\right.$ & 79.46 \\
\hline
\end{tabular}

Source: a. Ariyanti, (2016) [2]

b. Moraes et al., (2015) [9]

TABLE III. EFFECT OF PROPORTION OF FLOUR ADDITION TO PHYSICAL PROPERTIES OF DRIED NOODLE PRODUCTS

\begin{tabular}{|c|c|c|c|}
\hline Formula (wheat flour : MOSOF) & Cooking loss (\%) & Rehydration (\%) & Elastisitas (\%) \\
\hline $50: 50$ & $9.70^{\mathrm{a}}$ & $60.03^{\mathrm{a}}$ & $13.83^{\mathrm{a}}$ \\
\hline $60: 40$ & $9.65^{\mathrm{a}}$ & $58.83^{\mathrm{b}}$ & $13.75^{\mathrm{a}}$ \\
\hline $70: 30$ & $9.15^{\mathrm{b}}$ & $57.21^{\mathrm{c}}$ & $13.28^{\mathrm{b}}$ \\
\hline
\end{tabular}

Different letter supercript in the same column means significant difference $(\mathrm{p}<0.05)$

TABLE IV. EFFECT OF EGG ADDITION (\%) ON PHYSICAL PROPERTIES OF DRIED NOODLE PRODUCTS

\begin{tabular}{|l|l|l|l|}
\hline Addition of egg (\%) & Cooking loss $(\%)$ & Rehydration $(\%)$ & Elastisity $(\%)$ \\
\hline 15 & $9.36^{\mathrm{a}}$ & $58.18^{\mathrm{a}}$ & $13.47^{\mathrm{a}}$ \\
\hline 20 & $9.47^{\mathrm{a}}$ & $58.86^{\mathrm{b}}$ & $13.64^{\mathrm{b}}$ \\
\hline 25 & $9.70^{\mathrm{a}}$ & $59.03^{\mathrm{b}}$ & $13.75^{\mathrm{b}}$ \\
\hline
\end{tabular}

Different letter supercript in the same column means significant difference $(\mathrm{p}<0.05)$ 
TABLE V. THE INFLUENCE OF ADDITION PROPORTION OF FLOUR TO THE PROPERTIES OF CHEMICAL DRIED NOODLE PRODUCTS

\begin{tabular}{|c|c|c|c|}
\hline Formula (wheat flour : MOSOF) & Ash $(\% \mathrm{wb})$ & Moisture $(\% \mathrm{wb})$ & Proteins $(\% \mathrm{wb})$ \\
\hline $50: 50$ & $1.62^{\mathrm{a}}$ & $9.64^{\mathrm{a}}$ & $9.70^{\mathrm{a}}$ \\
\hline $60: 40$ & $1.54^{\mathrm{b}}$ & $9.53^{\mathrm{a}}$ & $9.66^{\mathrm{a}}$ \\
\hline $70: 30$ & $1.50^{\mathrm{c}}$ & $8.73^{\mathrm{b}}$ & $10.84^{\mathrm{b}}$ \\
\hline
\end{tabular}

Different letter supercript in the same column means significant difference $(\mathrm{p}<0.05)$

TABLE VI. THE EFFECT OF ADDITION OF EGG (\%) TO THE PROPERTIES OF CHEMICAL DRIED NOODLE PRODUCTS

\begin{tabular}{|l|l|l|l|}
\hline Egg Addition (\%) & Ash $(\% \mathrm{wb})$ & Moisture $(\% \mathrm{wb})$ & Proteins $(\% \mathrm{wb})$ \\
\hline 15 & $1.54^{\mathrm{a}}$ & $9.22^{\mathrm{a}}$ & $9.83^{\mathrm{a}}$ \\
\hline 20 & $1.56^{\mathrm{a}}$ & $9.27^{\mathrm{b}}$ & $10.09^{\mathrm{a}}$ \\
\hline 25 & $1.56^{\mathrm{a}}$ & $9.41^{\mathrm{b}}$ & $10.27^{\mathrm{a}}$ \\
\hline
\end{tabular}

Different letter supercript in the same column means significant difference $(\mathrm{p}<0.05)$

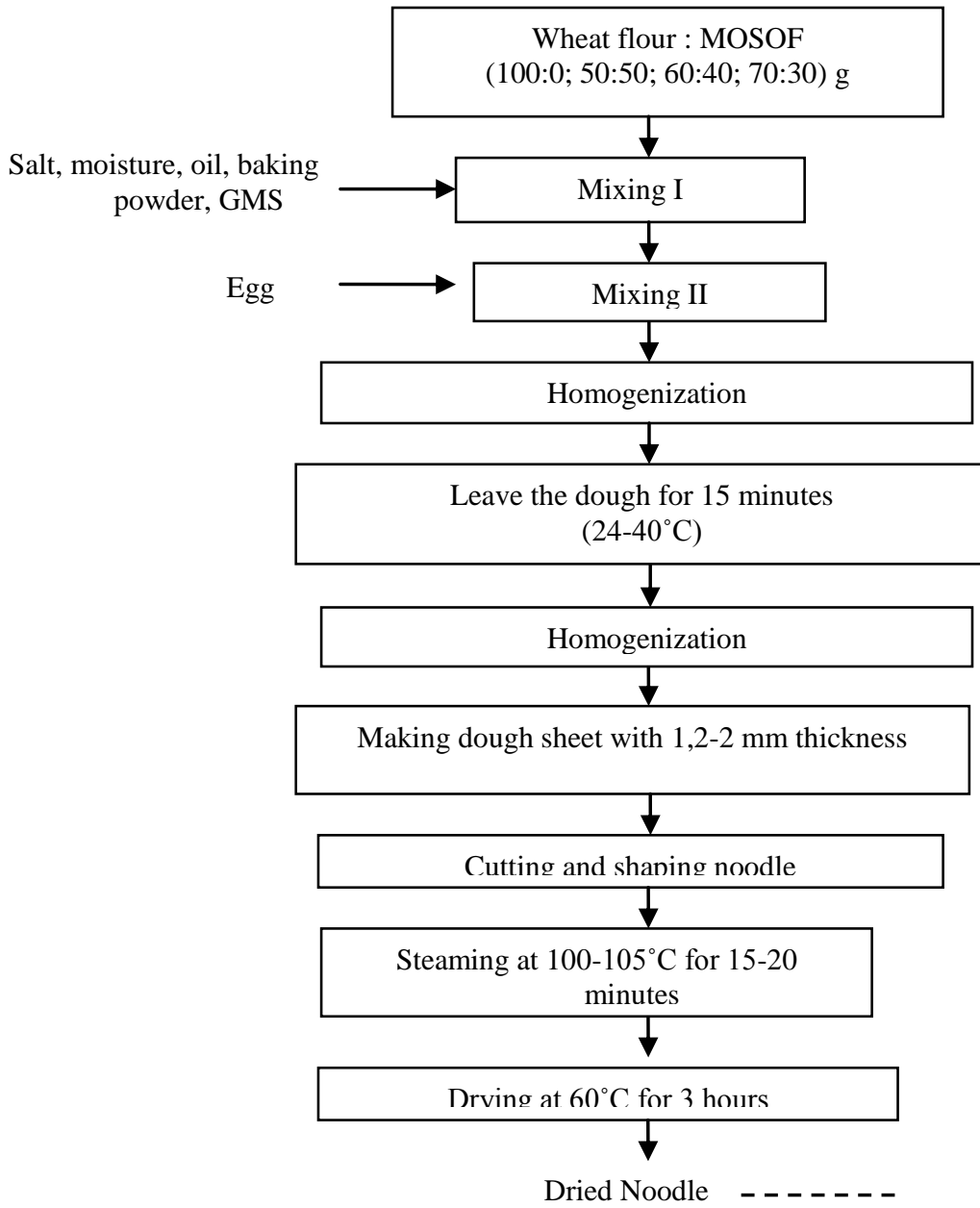

Fig. 1. Noodle Making Process [2]
Moisture, ash $(\% \mathrm{wb})$, proteins $(\% \mathrm{wb})$, starch $(\% \mathrm{wb})$, crude fiber (\%wb), cooking loss (\%), rehydration $(\%)$, elastisity $(\%)$

\section{RESULT AND DISCUSSION}

\section{A. Chemical Properties of MOSOF}

In this study, the results of chemical analysis of MOSOF was compared with literature, this aims to determine differences in the chemical properties of sorghum flour at the time before and after fermentation. The results of the analysis of modified sorghum flour (MOSOF) can be seen in Table 2.
As shown Table 2, in general the component values (\% wb) of moisture, protein and MOSOF starch were higher than sorghum flour. The higher moisture content in MOSOF is possible because of the role of amylose. Amylose has role to make rigid and strong gel formation, while the gel formed by amylopectin is not strong. It is suspected that the percentage of amylose in MOSOF starch is higher than amylopectin, so this has an impact on increasing moisture content. 
Higher protein and starch values in MOSOF may be due to the presence of moisture-soluble components that are lost during soaking, including anti-nutrition substances, namely tannin and phytate. Tannins are the main phenolic component found in sorghum and can form bonding complexes with macromolecular compounds [7]. In addition, tannin and phytic acid can also decrease due to fermentation process. The fermentation of sorghum by using lactic acid bacteria can reduce phytate and tannins $[8 ; 9 ; 10 ; 11]$.

Tanin is a phenolic component and the fermentation process can reduce its content in sorghum. The fermentation process can produce enzymes which can later depolarize phenolic components [12]. Fermentation can reduce phenolic components due to the condensation oxidation reaction of phenolic components [13]. Besides, fermentation can contribute to the reduction of tannins due to the separation between phenolic components and the separation between phenolic components with other components so that the impact on tannin extraction decreases $[14 ; 13 ; 11]$. Meanwhile, increasing protein and starch values of MOSOF can also defect on decresing content of ash and crude fiber of MOSOF.

\section{B. Physical and Chemistry Properties of MOSOF Dried} Noodle Products

In this test, two research factors were used namely the proportion of flour addition and egg addition. These two factors were determined the effect on physical and chemical properties of dried noodle products. Apparently there is no interaction between the two factors. The proportion influence of flour addition to physical and chemical can be seen in Table 2 and Table 5, respectively. Meanwhile, the proportion effect of egg addition (\%) on physical and chemical quality, each can be seen in Table 4 and Table 6.

In Table 3. it can be seen that the higher addition of MOSOF is in line with the increase of cooking loss (\%), rehydration $(\%)$ and elasticity $(\%)$. This can be seen from the first formula $(50: 50)$ which has the highest value $(\mathrm{p}<0.05)$ compared to other formulas. The higher addition of MOSOF, the greater the value of cooking loss. The value of cooking loss can be linked to the number of solid dried noodles that are dissolved in moisture during cooking process. MOSOF is sorghum flour which is modified by fermentation. The existence of the fermentation process with BAL may be cause substitution of starch hydroxyl groups with lactic acid, and the result is in the amorphous starch structure. Amorphous starch structure can affect the amount of solids dissolved during the cooking process of dried noodles. Besides, the structure of amorphous starch can increase rehydration $(\%)$ and have an impact on increasing elasticity $(\%)$.

The high addition of MOSOF also has an impact on increasing rehydration (\%) and it has increasing elasticity (\%) effect. This may be due to the high amylose content in MOSOF. MOSOF undergoes a modification process by fermentation, and it caused increasing on starch content which is $79.46 \% \mathrm{wb}$ (Table 2). It is suspected that an increase in starch $(\% \mathrm{wb})$ is linear with an increase in the amylose content of MOSOF. Amylose has a deeper ability to bind and to release moisture when compared to amylopectin. During the heating process, the starch gelatinization process occurs and causes the moisture to be trapped in starch granules. This is consistent as [15] that gelatinization is a process that causes the formation of starch gel due to the presence of starch hydration, namely the process of moisture absorption by starch molecules.

As shown in Table 4, it can be seen that the higher the percentage of egg addition, the higher value of rehydration and elasticity ( $p<0.05)$, but the cooking loss parameter is not significant ( $\mathrm{p}<0.05)$. Egg is one of proteins source. This result may be caused by the polarity properties of proteins, so that it can improve the ability of moisture binding and increase rehydration. The addition of egg to the manufacture of dried noodles can increase rehydration, this is due to the high proteins content and an increase in moisture binding. In addition, proteins also has functional properties to form gels, which can have an impact on increasing elasticity [16].

Table 5. shows that the moisture component (\%wb) in the formula with a ratio of wheat flour: MOSOF $=50: 50$ has the highest value $(\mathrm{p}<0.05)$. The higher the moisture content with the increasing addition of MOSOF may be to be caused by a lot of open starch structures due to the modification process and caused the starch structure becoming more amorphous, resulting in increased moisture content. This result is also consistent with the results in Table 3 which shows that the 50:50 formula has the highest rehydration (\%) and elasticity (\%). The results of proteins analysis showed that the formula $70: 30$ has greater proteins value $(\mathrm{wb} \%)$ than the others $(\mathrm{p}<0.05)$. The high proteins content in this formula may be influenced by the higher proteins content of flour. Wheat flour has a proteins content of $12.80 \%$ [3] compared to $\operatorname{MOSOF}(5.03 \% \mathrm{wb})$.

In Table 6. it can be seen that the addition of egg (20\%) has significant effect on increasing moisture $(\% \mathrm{wb})(\mathrm{p}<0.05)$, but not with the component of ash and proteins (\% wb). The increase of the moisture component can be caused by higher proteins due to the addition of egg, because proteins has functional properties to bind moisture due to its polar properties. There was no signinicant differences on ash treatment, this may be due to the lack of mineral content contained in the egg. The mineral composition of whole hen egg is $0.9 \%$ [17].

\section{IV.CONCLUSION}

The fermentation process tends to increase the chemical properties of sorghum flour, such as starch, protein and moisture. There is no interaction between the addition of wheat flour and MOSOF with the addition of egg to the physical and chemical properties of dried noodles. The use of flour with a proportion of 50:50 (flour: MOSOF) and egg 25\% was chosen as the best treatment, because it can improve the physical and chemical properties of dry noodle products, which include rehydration (\%), elasticity (\%), ash (\% wb ) and moisture (\% wb). 


\section{ACKNOWLEDGMENTS}

The author would like to thank LPPM UPN "Veteran" Jatim through RISDA Research Program which has provided research funding.

\section{REFERENCES}

[1] WINA, "Global Demand for Instant Noodles," unpublished, 2017.

[2] Y.R. Ariyanti, "Perubahan Fisiko Kimiawi Pada Proses Pengolahan Tepung Sorgum Termodifikasi," Thesis, Surabaya: Universitas Pembangunan Nasional "Veteran", unpublished, 2016.

[3] S.T.G. Al-Sahlany and A.M.S. Al-musafer, "Effect of Substitution Percentage Of Banana Peels Flour In Chemical Composition, Rheological Characteristics Of Wheat Flour And The Viability Of Yeast During Dough Time," J. Saudy Society Agricul. Sci., in press.

[4] AOAC, "Official Method of Analysis of the AOAC," 18th Ed, Maryland: AOAC International, 2005.

[5] S. Sudarmadji, B. Haryono, and Suhardi, Prosedur Analisa untuk Bahan Makanan dan Pertanian, Yogyakarta: Liberty, 1997.

[6] E.A. Moraes, R.S.Marineli, S.A. Lenquiste, C.J. Steel, C.B. de Menezes, V.A.V. Queiroz, and M.R.M. Júnior, "Sorghum Flour Fractions: Correlations Among Polysaccharides, Phenolic Compounds, Antioxidant Activity And Glycemic Index," Food Chem., vol. 180, pp. 116-123, 2015.

[7] J.M. Awika, L. Dykes, L. Gu, L.W. Rooney, and R.L. Prior, "Processing Of Sorghum (Sorghum Bicolor) and Sorghum Products Alters Procyanidin Oligomer And Polimer Distribution and Content," J. Agric. Food Chem., vol. 51, pp. 5516-5521, 2003.

[8] S. Alka, Y. Neelam, and S. Shruti, "Effect of Fermentation on Physicochemical Properties and in Vitro Starch and Proteins
Digestibility of Selected Cereals," Int. J. Agric. Food Sci., vol. 2, pp. 66$70,2012$.

[9] A.M.A. Elkareem and J.R.N. Taylor, "Proteins Quality and Physical Characteristics of Kisra (Fermented Sorghum Pancake Like Flatbread) Made From Tannin and Non-Tannin Sorghum Cultivars," Cereal Chem., vol. 88, pp. 344-348, 2011.

[10] A. Elmoneim, O. Elkhalifa, B. Schiffler, and R. Bernhardt, "Effect of Fermentation of the Functional Properties of Sorghum Flour," Food Chem., vol. 92, pp. 1-5, 2005.

[11] E. Towo, E. Matuschek, and U. Svanberg, "Fermentation and Enzyme Treatment of Tannin Sorghum Gruels: Effects on Phenolic Compounds, Phytate And In Vitro Accessible Iron," Food Chem., vol. 94, pp. 369376, 2006.

[12] N. Ben Othman, D.Roblain, N. Chammen, P.Thonart and M. Hamdi. Antioxidant Phenolic Compounds Loss During The Fermentation Of Chetoui Olives. Food Chem. 116, pp. 662-669. 2009.

[13] J.R.N. Taylor and K.G. Duodu, "Effects of Processing Sorghum and Millets on Their Phenolic Phytochemicals and the Implications of This to the Health-Enhancing Properties of Sorghum and Millet Food and Beverage Products,” J. Sci. Food Agric., vol. 95, pp. 225-237, 2015.

[14] E. Pablo, H.H. Siqueira, C. Damiani, E. Valério, and D.B. Vilas, "Physicochemical and Sensory Characteristics of Snack Bars Added of Jerivá Flour (Syagrus romanzoffiana), vol. 36, pp. 421-425, 2016.

[15] Haryadi, "Modified Cassava Flour Technology," Agritech, vol. 31, pp. 86-92, 1993.

[16] U.L. Biyumna, S.W. Wiwik, and D. Nurud, "Karakteristik Mie Kering Terbuat dari Tepung Sukun (Artocarpus altis) dan Penambahan Telur," Jurnal Agroteknologi Vol. 11 (01): 23-34. 2017.

[17] F.G. Winarno and S. Koswara, "Telur: Komposisi, Penanganan dan Pengolahannya," Bogor: M-Brio Press, 2002. 